\title{
EFFECT OF PUMPKIN SEEDS AND SPICES ON PHYSICOCHEMICAL AND SENSORY CHARACTERISTICS OF READY TO EAT PANEER
}

\section{ARUN KUMAR. H, USHA RANI \& HARINIVENUGOPAL}

Dairy Science College, KVAFSU, Bengaluru, India

APSTRACT
Paneer is the most popular indigenous dairy products in India with a significant annual growth rate. It is a rich source
of protein and fat contents. But it is deficient in iron and fiber contents. Hence an attempt has been made to incorporate
pumpkin seeds as it contains substantial amounts of fiber and iron. Pumpkin seeds are blended at the rate of 3, 6, 9 and
12 per cent. Among these levels, 6 per cent was found to be significantly higher acceptability score of 8.66 compared to
control. Further, the product also contains significantly higher amounts of iron and fiber at 1.52 mg/100 g and 1.7 per
cent respectively without affecting any sensory characteristics. Further mixed spices pepper: garlic: ginger (1:1:1) were
blended at different levels and at 1 per cent blended level found more acceptable.
KEYWORDS: Paneer, Spices, Fiber, Iron \& Flavour

Received: Mar 26, 2021; Accepted: Apr 16, 2021; Published: Jun 09, 2021; Paper Id: IJASRJUN202121

\section{INTRODUCTION}

The major portion of milk produced in India is being consumed as liquid form and the almost same amount of remaining milk is used to prepare milk products. Approximately $7 \%$ of the total milk produced is converted to paneer (Indian soft cheese). In the present scenario, consumers are more conscious about their health and they are shifting towards foods which provide health benefits beyond basic nutrition by adopting "functional foods" that are going to improve their health and wellbeing too. In fact, blending functional ingredients into dairy-based foods help in increased nutritional value as well as the sale of dairy foods.

Spices have been used for many centuries across different regions of the world toimprove the aroma, flavor of food substances, as well as to preserve food and for treatment ofdifferent diseases. Herbs and spices are gaining importance nowadays because of theirantioxidantcontent,cancerpreventionactionimproveshearthealthandantiinflammatoryaction.

Pumpkin seeds are consumed as raw, roasted or cooked and/or to make delicious dishes like payasam, chutney etc., only at domestic scale. Pumpkin seed is rich source of fat, protein, dietary fiber, minerals (iron, zinc, manganese and potassium), vitamins, polyunsaturated fatty acids and phytosterols. The oil content of pumpkin seed ranged from 11-31\%, total unsaturated fatty acid content ranged from 73 to $81 \%$, the predominant are linoleic, oleic, palmitic and stearic acids. They are being regarded valuable for the food industry. Also, these have beneficial effects on blood glucose level, immunity, heart health, bladder function and parasitic inhibition Seema (2013). Hence an attempt has been made to assess the effect of pumpkin seeds on the quality of ready to eat paneer were studied. 


\section{MATERIALS AND METHODS}

Fresh cow milk was procured from the Students Experimental Dairy Plant (SEDP), Dairy science college, Food grade citric acid used as a milk coagulant (coagulating agent) in the preparation of paneer. Pumpkin seeds, salt, spices were purchased from the supermarket. Based on preliminary trials salt level in the product was optimized to 1.5 per cent.

\section{Preparation of Paneer}

Paneer was prepared as per the method suggested by Bhattacharya et al. (1971) with slight modifications. The standardized milk $3.5 \%$ fat and $8.5 \%$ MSNF was heated to $90^{\circ} \mathrm{C}$ (No holding) in a stainless steel vessel followed by cooling to $70^{\circ} \mathrm{C}$. Then hot solution $\left(70^{\circ} \mathrm{C}\right)$ of one percent citric acid was added to the milk $\left(70^{\circ} \mathrm{C}\right)$ with vigorous agitation initially and gentle stirring later till clear whey was separated out. The coagulum was then allowed to settle down for 5 minutes. The whey was drained out through a muslin cloth and collected paneer curd was used for the preparation of paneer.

\section{Flow Chart for the Preparation of Control Paneer}

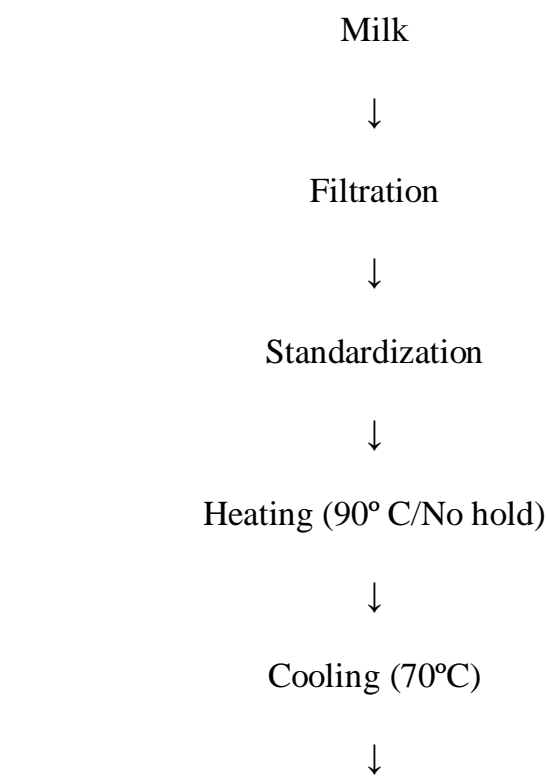

Addition of citric acid @ 1\% coagulant

Draining of whey

$\downarrow$

Pressing $\left(2-3 \mathrm{~kg} / \mathrm{cm}^{2} / 10-15 \mathrm{~min}\right)$

Immersion of paneer blocks in chilled water $\left(4^{\circ} \mathrm{C}\right)$

$\downarrow$

Packaging and storage at $4^{\circ} \mathrm{C}$

Fat, acidity content of milk was determined by Gerber method as IS: 1479 (part I) 1981. 


\section{Milk Solids Not Fat (MSNF)}

MSNF content in milk was estimated by using BIS Lactometer by using the following formula. SNF $(\%)=0.25 \mathrm{CLR}+0.2 \mathrm{~F}$ +0.48. Where CLR-Corrected Lactometer Reading and F-Fat (content in per cent). Fat, protein and moisture contents of paneer were determined as per the IS: SP18 (Part XI) 1981. The titratable acidity of paneer was determined as per the procedure of $\mathrm{AOAC}(33.7 .14 ; 920.124,1995)$.

Production of Value added Ready-to-Eat Paneer

Milk

$\downarrow$

Filtration

$\downarrow$

Standardization (Fat 3.5\%, SNF: 8.5)

$\downarrow$

Heating $\left(90^{\circ} \mathrm{C} /\right.$ no hold $)$

$\downarrow$

Cooling $\left(70^{\circ} \mathrm{C}\right)$

$\downarrow$

Coagulation by addition of $2 \%$ citric acid solution

Draining of whey

$\downarrow$

Mixed Spices @ 0.5\%,1.0\% and 1.5\%., pumpkin seeds @ 3\%,6\%,9\%,\& 12\%) weight of paneer.

$\downarrow$

Pressing $\left(2-3 \mathrm{~kg} / \mathrm{cm}^{2} / 10-15 \mathrm{~min}\right)$

$\downarrow$

Storage at $7^{\circ} \mathrm{C}$

\section{RESULTS AND DISCUSSIONS}

Effect of Different Levels of Pumpkin Seeds on the Sensory Characteristics of Ready to Eat Paneer (RTEP)

It was revealed from the data that the addition of pumpkin seeds at above 6 per cent level, the overall acceptability scores were decreasing trend. As the level of pumpkin seeds in paneer increased from 0 to 12 percent, the scores had a significant effect on the scores of color and appearance. It could be due to dull appearance of the product at higher levels of pumpkin seeds. Similarly, Giami (2005) also reported the dark-coloured cookies in pumpkin seed flour blended at above 20 per cent levels. This indicates pumpkin seed products are susceptible to heat at above boiling or baking temperature causes darkening of the final product. The body and texture scores also shown decreasing trend as the level of pumpkin seeds increased in 
paneer. However, there was no significant difference between the scores of the control sample and paneer added with 3 and 6 percent pumpkin seeds which had scores of $8.45,8.47$ and 8.56 respectively. The product was found to be more viscous at 9 and 12 per cent pumpkin seeds added paneer and showed significantly $(\mathrm{P} \leq 0.05)$ lowered scores.

The mean sensory scores for flavor of control sample was 8.57 as against $8.57,8.68,7.81$ and 6.80 respectively for paneer added with pumpkin seeds at 3, 6,9 and 12 per cent levels respectively. It was recorded that the sample with 3 per cent was comparable with the control sample, whereas, the lowest score was awarded to product with 9 and 12 per cent sample. This may be due to the detectable raw beany flavor and after taste of the pumpkin seeds. Judges also noticed raw beany flavor in 9 and 12 per cent levels of pumpkin seeds.

The sensory scores awarded for overall acceptability of paneer was 8.54 for control sample as against $8.58,8,66$, 7.91 and 6.81 for paneer added with different levels i.e., 3, 6, 9 and 12 per cent pumpkin seeds respectively. The product prepared by using pumpkin seeds at 6 per cent level was found significantly $(\mathrm{P} \leq 0.05)$ better compared to other samples, due to presence of optimal nutty flour, good consistency or body of the product but at higher levels of pumpkin seeds product showed significantly lower scores with respect to overall acceptability, this could be due to the observed beany flavor, hard or more viscous and crumbly texture. Similar results were reported by Giami (2005) in cookies and Nyam et al., (2013) in bread.

\section{Effect of Different Levels of Pumpkin Seeds on Chemical Characteristics of Ready to Eat Paneer(RTEP)}

From the results pertaining to the effect of the addition of pumpkin seeds on the chemical composition of paneer, it is evident that addition of pumpkin seeds affects the moisture, fat and protein, iron and water activity contents significantly. It was revealed from the data that as the level of addition of pumpkin seeds increased from 0 to 12 per cent, the moisture content significantly $(\mathrm{P} \leq 0.05)$ decreased to 47.30 from 52.46 per cent. The moisture content decreased with increasing pumpkin seeds level, due to increased total solids content in the product. Similar findings have been reported but values obtained were lower as compared to Neeta et al.(2020) where they used germinated pumpkin seeds in the bakery products. It is evident from the Table that, there was a significant increase in fat and protein content of ready to eat paneer with increase in pumpkin seeds level from $0-12$ percent reported increase in fan content from 20.26 to 23.34 percent, whereas protein content increased from 17.96 to 19.26 per cent. The highest fat and protein content reported to the sample treated with 12 per cent pumpkin seeds. Level of addition of pumpkin seeds increased from 0 to 12 per cent, the water activity decreased 0.964 from 0.980 due to variation in the moisture content of the product. Giami and Bekebain,(1992) reported that addition of pumpkin seeds resulting in lower water activity, melting rate and penetration values. This results harder body in cookies supplemented with pumpkin seeds. The iron content increased from the initial value of $1.10 \mathrm{mg}$ per $100 \mathrm{gm}$ to $1.92 \mathrm{mg}$ per $100 \mathrm{gm}$. Similar findings are reported by Giami et al 2005 in pumpkin seed flour incorporated products. Malkanthi et al. (2018) observed that pumpkin seed powder was rich in protein, fat, fiber, bet-carotene, iron and zinc. From the results it is confirmed that the utilization of pumpkin seeds in RTE Paneernot only improves the sensory characteristics but also showed significantly improved iron and fiber contents in the paneer, hence it can be called as value added RTE product, the iron and fiber contents are the major deficient in the dairy products prepared with milk alone. 
Effect of Different Levels of Spices (Pepper:Garlic:Gingerat1:1:1)on the Sensory Characteristics of Ready to Eat Paneer (RTEP)

There was a significant reduction in colour and appearance scores of the sample prepared by using spices at 1.5 per cent level due to presence of fine dark particles which are present in spices (Table-3). There is no significant difference between the body and texture scores of control and treated sample. This indicates incorporation of spices per cent level causes slight reduction in sensory scores value at non-significant level.

Among experimental samples, 1.0 per cent spices treated sample was awarded highest flavor score of 8.49 and was highly acceptable by the judges compare to control sample and other treated samples. At higher level of incorporation of (1.5 per cent) mixedspices, paneer was highly harsh, pungent and had strong medicinal flavor as opinioned byjudges.Paneer preparedbyincorporationofmixedspicesat1.0percentlevelin1:1:1ratiowas found highly acceptable compared to control sample and other experimental samples.

The highest overall acceptability score awarded to sample prepared by in corporating 1.0 per cent level of spices found to be optimum and it was significantly superior to that of control sample. Further increasing level of mixed spices had significantly decreased sensory scores. This may be due to strong flavors observed by the judges. These results are similar with Himabindu, 2017 who reported that incorporation of 1.0 per cent levels of mixed spice powder (garlic, ginger, black pepper) to cottage cheese secured optimum score.

\section{CONCLUSIONS}

The developed paneer had optimal levels of salt, pumpkin seeds and spices not only improve the functional properties but also increase the nutritional quality. Thus final product contains a substantial amount of fiber and iron, these are naturally absent in milk and milk products. Hence developed product Ready-To-Eat Paneer has a high potential for commercialization.

Table 1: Effect of Different Levels of Pumpkin Seeds on The Sensory Characteristics of Value Added Ready to Eat Paneer(RTEP).

\begin{tabular}{|c|c|c|c|c|}
\hline $\begin{array}{c}\text { Pumpkin Seeds } \\
\text { Percent }\end{array}$ & $\begin{array}{c}\text { Colour and } \\
\text { Appearance }\end{array}$ & $\begin{array}{c}\text { Body and } \\
\text { Texture }\end{array}$ & Flavour & Overall Acceptability \\
\hline Control & $8.20^{\mathrm{a}}$ & $8.45^{\mathrm{a}}$ & $8.57^{\mathrm{a}}$ & $8.54^{\mathrm{a}}$ \\
\hline 3.0 & $8.22^{\mathrm{a}}$ & $8.47^{\mathrm{a}}$ & $8.59^{\mathrm{a}}$ & $8.58^{\mathrm{a}}$ \\
\hline 6.0 & $8.32^{\mathrm{a}}$ & $8.56^{\mathrm{a}}$ & $8.68^{\mathrm{b}}$ & $8.66^{\mathrm{b}}$ \\
\hline 9.0 & $8.11^{\mathrm{b}}$ & $8.15^{\mathrm{b}}$ & $7.81^{\mathrm{c}}$ & $6.91^{\mathrm{c}}$ \\
\hline 12.0 & $7.94^{\mathrm{b}}$ & $8.04^{\mathrm{b}}$ & $6.80^{\mathrm{d}}$ & $\mathbf{0 . 0 7}$ \\
\hline $\mathrm{CD}(P \leq 0.05)$ & $\mathbf{0 . 1 8}$ & $\mathbf{0 . 1 6}$ & $\mathbf{0 . 0 6}$ & \\
\hline $\begin{array}{l}\text { Note: All the values are average of } 3 \text { trials. } \\
\text { NS - Non significant } \\
\text { Similar superscripts indicate non-significance at the corresponding critical difference }(\mathrm{CD})\end{array}$ \\
\hline
\end{tabular}

Table 2: Effect of Different Level of Pumpkin Seeds on Chemical Characteristics of Ready To Eat Paneer(RTEP)

\begin{tabular}{|c|c|c|c|c|c|c|c|}
\hline \multirow{2}{*}{$\begin{array}{l}\text { Pumpkin } \\
\text { Seeds } \\
\text { Percent }\end{array}$} & \multicolumn{3}{|c|}{ Percent \% } & \multirow{2}{*}{$\begin{array}{l}\text { Acidity } \\
(\% \text { LA) }\end{array}$} & \multirow{2}{*}{$\begin{array}{c}\text { Water activity } \\
\qquad\left(\mathbf{a}_{w}\right)\end{array}$} & \multirow{2}{*}{$\begin{array}{c}\text { Iron } \\
\text { mg/100gm }\end{array}$} & \multirow{2}{*}{$\begin{array}{c}\text { Fibre } \\
(\%)\end{array}$} \\
\hline & Moisture & Fat & Protein & & & & \\
\hline Control & $52.46^{\mathrm{a}}$ & $20.26^{\mathrm{a}}$ & $17.96^{\mathrm{a}}$ & $0.23^{\mathrm{a}}$ & $0.980^{\mathrm{a}}$ & $1.1^{\mathrm{a}}$ & $0.33^{\mathrm{a}}$ \\
\hline $3 \%$ & $51.06^{\mathrm{b}}$ & $21.09^{\mathrm{b}}$ & $18.31^{\mathrm{a}}$ & $0.23^{a}$ & $0.976^{\mathrm{b}}$ & $1.32^{\mathrm{b}}$ & $1.30^{\mathrm{b}}$ \\
\hline $6 \%$ & $49.74^{\mathrm{c}}$ & $21.88^{c}$ & $18.65^{b}$ & $0.24^{\mathrm{a}}$ & $0.972^{\mathrm{c}}$ & $1.52^{\mathrm{c}}$ & $1.70^{\mathrm{c}}$ \\
\hline $9 \%$ & $48.50^{d}$ & $22.63^{d}$ & $18.97^{\mathrm{b}}$ & $0.25^{\mathrm{a}}$ & $0.968^{\mathrm{d}}$ & $1.66^{\mathrm{d}}$ & $1.90^{\mathrm{d}}$ \\
\hline $12 \%$ & $47.30^{\mathrm{e}}$ & $23.34^{\mathrm{e}}$ & $19.26^{\mathrm{bc}}$ & $0.26^{\mathrm{a}}$ & $0.964^{\mathrm{e}}$ & $1.92^{\mathrm{e}}$ & $2.00^{\mathrm{d}}$ \\
\hline $\mathrm{CD}(\mathrm{P} \leq 0.05)$ & 0.88 & 0.68 & 0.42 & NS & 0.003 & 0.13 & 0.19 \\
\hline
\end{tabular}


Table 3: Effect of Different Level of Spices (Pepper:Garlic:Ginger@ 1:1:1)on the Sensory Characteristics of Ready to Eat Paneer(RTEP)

\begin{tabular}{|c|c|c|c|c|}
\hline Spices percent & $\begin{array}{c}\text { Colour and } \\
\text { Appearance }\end{array}$ & $\begin{array}{c}\text { Body and } \\
\text { Texture }\end{array}$ & Flavour & $\begin{array}{c}\text { Overall } \\
\text { Acceptability }\end{array}$ \\
\hline Control & $8.18^{\mathrm{a}}$ & $8.43^{\mathrm{a}}$ & $8.33^{\mathrm{a}}$ & $8.31^{\mathrm{a}}$ \\
\hline$(0.5)$ & $8.20^{\mathrm{a}}$ & $8.40^{\mathrm{a}}$ & $8.35^{\mathrm{a}}$ & $8.34^{\mathrm{a}}$ \\
\hline$(1.0)$ & $8.22^{\mathrm{a}}$ & $8.37^{\mathrm{a}}$ & $8.49^{\mathrm{b}}$ & $8.46^{\mathrm{b}}$ \\
\hline$(1.5)$ & $7.45^{\mathrm{b}}$ & $8.16^{\mathrm{a}}$ & $7.64^{\mathrm{c}}$ & $7.54^{\mathrm{c}}$ \\
\hline $\mathrm{CD}(\mathrm{P} \leq 0.05)$ & $\mathbf{0 . 1 5}$ & $\mathbf{N S}$ & $\mathbf{0 . 1 2}$ & $\mathbf{0 . 1 1}$ \\
\hline $\begin{array}{l}\text { Note: All the values are average of 3 trials.NS- Non-significant } \\
\text { Similarsuperscriptsindicatenon-significanceatthecorrespondingcriticaldifference(CD) }\end{array}$ \\
\hline
\end{tabular}

\section{REFERENCES}

1. AOAC., (1960). Official methods of analysis, $13^{\text {th }}$ Ed., Association of official analyticalchemists, Washington, DC.

2. N. Harish, K. Anil Kumar, D. Srinivas \& Sivala Kumar, “Advance Technology for Spices Grinding- A Review”, International Journal of Agricultural Science and Research (IJASR) ,Vol. 7, Issue 4,pp, 529-536

3. Bhattacharya, D.C., Mathur, O.N., Srinivasan, M. R. and Samlik,O.,

4. Studies on the method of production and shelf life of paneer. J. Food Sci.Technol.,8(5):117-120.

5. S. kavinkesinikethan, Dr. S. Selvanayaki \& Dr. T. Samsai, "Consumer Preference for Branded Spice Powders in Erode City”,International Journal of Agricultural Science and Research (IJASR),Vol. 9, Issue 4,pp, 173-180

6. Giami, S.Y., Simeon, C., Achinewhu and Christiana, 2005.Thequalityand sensory attributes of cookies supplemented with fluted pumpkin(TelfairiaoccidentalisHook)seedflour.

Int.J.FoodSci.Tech.,40(6):613-620.

7. Jisnu K. Patel, K. S. Jadav \& H. C. Parmar, “An Analysis of Resource Use Efficiency of Drip and Conventional Chilli Farm in Middle Gujarat ",International Journal of Humanities and Social Sciences (IJHSS) , Vol. 3, Issue 3,pp, 85-92

8. Giami,S.Y. and Bekebain,D.A. (1992). Proximate composition and functional properties of raw and processed full-fat fluted pumpkinseed (Telfairiaoccidentalis) flour. Journal the Science of Food and Agriculture, 59:321- 325.

9. Offia Olua, b. i., Eluwa, q. c. \& Abuajah, c"Incorporation of Papain into Ice Cream: Impact on Pawpaw (Carica Papaya) Ice Cream Quality”, IASET: International Journal of Biology, Biotechnology and Food Science (IASET: IJBBFS), Vol. 1, Issue 1,pp; 7-22

10. Himabindu, D. 2017. Process optimization for the Development of spiced cottagecheese. MTech. Thesis submitted to Karnataka Veterinary, Animal and FisheriesSciencesUniversities, Bidar.

11. IS: SP: 18, 1981. ISI Handbook of Food Analysis, part XI, Dairy products, Bureau IndianStandards, New Delhi,India.

12. Malkanthi, H.H.A.,Umadevi,S.H. andJamuna K.V.,2018.Glycemic response

13. andantioxidantactivityofpumpkinseedpowder(Cucurbitamaxima)blendedbiscuits.Journal of Pharmacognosyand Phytochemistry.7(4): 1877-1882

14. Neeta,K.,Sangeeta,C.,Sindhu., Varsha.,K.andVarsha Rani.,2020.

15. Nutritionalevaluationofdevelopedvalue-addedbiscuitsincorporatinggerminatedpumpkin seed flour. Journal of Pharmacognosy and Phytochemistry., 9(5): 2802-2806. 
16. Nyam, K.L., Lau, M.and Tan, C. P., 2013. Fiber from Pumpkin (Cucurbita pepo L.)SeedsandRinds:PhysicochemicalProperties,AntioxidantCapacityandApplicationasBakeryProductIngredients.MalaysianJournalofNutrition, 19(1):99109.

17. Seema Patel., 2013. Pumpkin (cucurbita sp.) seeds as nutraceutic: A review on status quo and scopes. Bioinformatics and medical informatics research center, springer-verlag Italia,6-12. 
